\title{
Cholinergic Stimulation of AP-1 and NF $\kappa$ B Transcription Factors Is Differentially Sensitive to Oxidative Stress in SH-SY5Y Neuroblastoma: Relationship to Phosphoinositide Hydrolysis
}

\author{
Xiaohua Li, Ling Song, and Richard S. Jope \\ Department of Psychiatry and Behavioral Neurobiology, University of Alabama at Birmingham, Birmingham, Alabama \\ 35294-0017
}

Oxidative stress appears to contribute to neuronal dysfunction in a number of neurodegenerative conditions, notably including Alzheimer's disease, in which cholinergic receptor-linked signal transduction activity is severely impaired. To test whether oxidative stress could contribute to deficits in cholinergic signaling, responses to carbachol were measured in human neuroblastoma SH-SY5Y cells exposed to $\mathrm{H}_{2} \mathrm{O}_{2}$. DNA binding activities of two transcription factors that are respondent to oxidative conditions, $\mathrm{AP}-1$ and $\mathrm{NF} \kappa \mathrm{B}$, were measured in nuclear extracts. $\mathrm{H}_{2} \mathrm{O}_{2}$ and carbachol individually induced doseand time-dependent increases in AP-1 and NF $\kappa \mathrm{B}$. In contrast, when given together, $\mathrm{H}_{2} \mathrm{O}_{2}$ concentration dependently (30-300 $\mu \mathrm{M})$ inhibited the increase after carbachol in AP-1. Carbachol's stimulation of NF $\kappa \mathrm{B}$ was not inhibited except with a high concentration $(300 \mu \mathrm{M})$ of $\mathrm{H}_{2} \mathrm{O}_{2}$, which was associated with impaired activation of protein kinase $\mathrm{C}$. Lower concentrations of $\mathrm{H}_{2} \mathrm{O}_{2}(30-300 \mu \mathrm{M})$ inhibited carbachol-induced $\left[{ }^{3} \mathrm{H}\right]$ phosphoinositide hydrolysis, and this inhibition correlated $(r=0.95)$ with the inhibition of carbachol-induced AP-1. Activation of $\left[{ }^{3} \mathrm{H}\right]$ phosphoinositide hydrolysis by the calcium ionophore ionomycin was unaffected by $\mathrm{H}_{2} \mathrm{O}_{2}$, indicating that phospholipase $\mathrm{C}$ and phosphoinositides were impervious to this treatment. In contrast, activation with $\mathrm{NaF}$ of G-proteins coupled to phospholipase $\mathrm{C}$ was concentration dependently inhibited by $\mathrm{H}_{2} \mathrm{O}_{2}$, indicating impaired G-protein function. These effects of $\mathrm{H}_{2} \mathrm{O}_{2}$ are similar to signaling impairments reported in Alzheimer's disease brain, which involve deficits in receptor- and G-proteinstimulated phosphoinositide hydrolysis, but not phospholipase $\mathrm{C}$ activity. Thus, these findings indicate that oxidative stress may contribute to impaired phosphoinositide signaling in neurological disorders in which oxidative stress occurs, and that oxidative stress can differentially influence transcription factors activated by cholinergic stimulation.

Key words: oxidative stress; transcription factors; $A P-1$; $N F \kappa B$; phosphoinositide; cholinergic signaling
Oxidative stress appears to be one of the primary factors contributing to neuronal dysfunction in a number of debilitating conditions, potentially including Alzheimer's disease, aging, and epilepsy (Halliwell, 1992; Coyle and Puttfarcken, 1993; Shigenaga et al., 1994). Activation of two transcription factors, AP-1 and $\mathrm{NF} \kappa \mathrm{B}$, represents cellular signaling processes that are particularly responsive, or susceptible, to oxidative stress (Abate et al., 1990; Staal et al., 1990). Thus, it has been reported that exposure of a variety of cell types to oxidants induces increases in both AP-1 and $\mathrm{NF} \kappa \mathrm{B}$ DNA binding, as measured by the electrophoretic mobility shift assay (EMSA) (for review, see Karin and Smeal, 1992; Siebenlist et al., 1994). Therefore, activation of these two transcription factors comprises potentially important signaling pathways for mediation of cellular responses to oxidative stress, which can range from adaptive mechanisms, such as the induction of antioxidant enzymes, to terminal signals leading to cell death.

Activation of $\mathrm{AP}-1$ and $\mathrm{NF} \kappa \mathrm{B}$ in many cases constitutes a downstream consequence of signaling pathways that activate protein kinase C (for review, see Karin and Smeal, 1992; Siebenlist et al., 1994). For example, the phosphoinositide signal transduction system, in which receptors coupled to the G-proteins Gq and G11

\footnotetext{
Received April 23, 1996; revised July 1, 1996; accepted July 8, 1996.

This work was supported by National Institutes of Health Grant AG06569.

Correspondence should be addressed to Dr. Richard S. Jope, Department of Psychiatry and Behavioral Neurobiology, Sparks Center 1057, University of Alabama at Birmingham, Birmingham, AL 35294-0017.

Copyright (C) 1996 Society for Neuroscience $0270-6474 / 96 / 165914-09 \$ 05.00 / 0$
}

stimulate phospholipase $\mathrm{C}$ to hydrolyze phosphoinositides, activates protein kinase $\mathrm{C}$ subsequent to diacylglycerol production from the cleaved phosphoinositides (Fisher, 1995). Protein kinase $\mathrm{C}$ activates both AP-1, by altering the phosphorylation state of the Jun and Fos immediate early gene proteins, and NF $\kappa \mathrm{B}$, by phosphorylating the inhibitory protein IkB and reducing its interactions with the transcription factor proteins (Karin and Smeal, 1992; Finco and Baldwin, 1995). Thus, in many cells agents that activate phosphoinositide hydrolysis have been shown to stimulate protein kinase $\mathrm{C}$ and to increase $\mathrm{AP}-1$ and $\mathrm{NF} \kappa \mathrm{B}$ DNA binding activities as measured by the EMSA with nuclear extracts. Both the AP-1 and $\mathrm{NF} \kappa \mathrm{B}$ transcription factors are composed of protein dimers. Members of the Jun and Fos protein families interact to form a heterogeneous mixture of AP-1 dimers, which are usually detected as a single band using the EMSA. NF $\kappa \mathrm{B}$ consists of dimers of two families of proteins, exemplified by $\mathrm{p} 50$ and p65 (RelA), which are often resolved into two or more bands by the EMSA.

The purpose of this investigation was to test whether oxidative stress modulated the activation of $\mathrm{AP}-1$ and $\mathrm{NF} \kappa \mathrm{B}$ transcription factors induced by stimulation of the phosphoinositide signal transduction system in neuronal cells. Focus was placed on identifying the consequences of oxidative stress on stimulation by carbachol of cholinergic muscarinic receptor-associated responses. This is of special interest because oxidative stress has been linked to neuronal dysfunction in Alzheimer's disease (Behl et al., 1994; Friedlich and Butcher, 1994; Hensley et al., 1994), in 
(A) AP-1

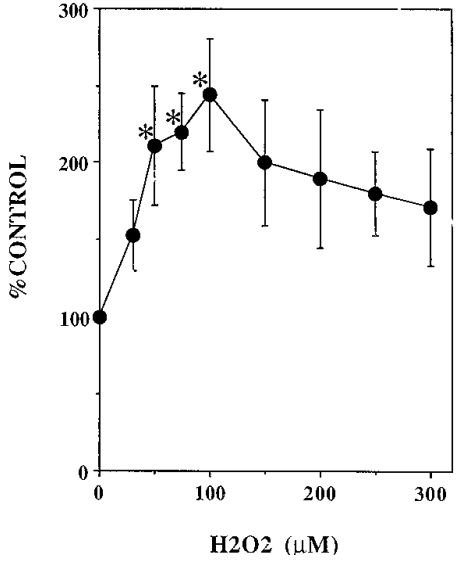

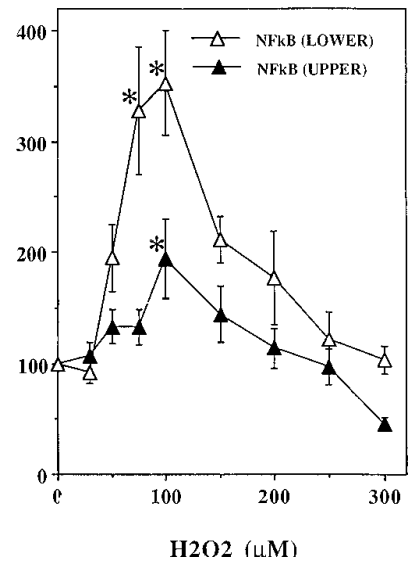

(B) NFkB

Figure 1. Concentration-dependent effects of $\mathrm{H}_{2} \mathrm{O}_{2}$ on AP-1 $(A)$ and $\mathrm{NF} \kappa \mathrm{B}(B)$ DNA binding activities. SH-SY5Y cells were exposed to $30-300$ $\mu \mathrm{M} \mathrm{H}_{2} \mathrm{O}_{2}$ for $2 \mathrm{hr}$. Cells were harvested, nuclear extracts were prepared, and $\mathrm{AP}-1$ and $\mathrm{NF} \kappa \mathrm{B}$ DNA binding activities were measured by EMSA as described in Materials and Methods. Two NF $\kappa$ B bands were resolved and are designated as UPPER and LOWER to indicate the slower and faster mobilities, respectively. Values are given as the percent of controls that were not exposed to $\mathrm{H}_{2} \mathrm{O}_{2}$. Mean \pm SEM. $n=6-7 .{ }^{*} p<0.05$ compared with control values (ANOVA with a post hoc Dunnett multiple comparisons test).

which there is a severe impairment of cholinergic activity that includes a large deficit in carbachol-induced phosphoinositide signaling (Greenwood et al., 1995) (for review, see Jope, 1996). Thus, the goal was to determine whether there could be a direct link between deficits in cholinergic receptor-induced signaling and oxidative stress in Alzheimer's disease. To test the possibility that oxidative stress may directly impair responses to cholinergic stimulation, cultured human neuroblastoma SH-SY5Y cells, which have been used widely to study muscarinic receptor function (Fisher, 1995), were exposed to $\mathrm{H}_{2} \mathrm{O}_{2}$ to induce oxidative stress, and the effects on signaling processes leading to activation of the $\mathrm{AP}-1$ and $\mathrm{NF} \kappa \mathrm{B}$ transcription factors were examined.

\section{MATERIALS AND METHODS}

Cell culture. Human neuroblastoma SH-SY5Y cells (kindly provided by Dr. S. K. Fisher, University of Michigan) were grown in $100 \mathrm{~mm}$ culture dishes (Corning, Corning, NY) in RPMI medium (Cellgro, Herndon, VA) containing 5\% fetal clone II (Hyclone, Logan, UT), $10 \%$ horse serum, $2 \mathrm{~mm}$ L-glutamine, $100 \mathrm{U} / \mathrm{ml}$ penicillin, and $100 \mu \mathrm{g} / \mathrm{ml}$ streptomycin. Cells were plated at a density of $10^{5}$ cells per dish and were harvested $\sim 48-72 \mathrm{hr}$ later, after the treatments described in Results.

MTT assay. The method of Hansen et al. (1989) was used to measure MTT (3-(4,5-dimethylthiazol-2-yl)-2,5-diphenyl tetrazolium bromide) reduction. Cells $\left(7 \times 10^{4}\right.$ cells/well) were grown in 24 -well plates for $48 \mathrm{hr}$, $\mathrm{H}_{2} \mathrm{O}_{2}(50,100$, or $300 \mu \mathrm{M})$ was added, and after $15,30,60$, or $120 \mathrm{~min}$ MTT $(1 \mathrm{mg} / \mathrm{ml})$ was added. After $20 \mathrm{~min}$ incubation at $37^{\circ} \mathrm{C}$, lysis buffer was added (10\% SDS, $25 \%$ dimethylformamide, $\mathrm{pH} 4.7)$. After incubation overnight at $37^{\circ} \mathrm{C}$, absorbance at $570 \mathrm{~nm}$ was measured in duplicate with a microtiter plate reader. Data are expressed as the percent of values obtained with cells not exposed to $\mathrm{H}_{2} \mathrm{O}_{2}$.

EMSA. To prepare nuclear extracts, cells were washed two times with PBS, and $4 \mathrm{ml}$ of lysis buffer (10 mM Tris, pH 7.4, $3 \mathrm{~mm} \mathrm{MgCl}_{2}, 10 \mathrm{~mm}$ $\mathrm{NaCl}, 0.5 \% \mathrm{NP} 40$ ) was added. Lysed cells were centrifuged at $4000 \times g$ for $5 \mathrm{~min}$ at $4^{\circ} \mathrm{C}$. The pellet was resuspended in $30 \mu \mathrm{l}$ of buffer containing $20 \mathrm{~mm}$ HEPES, pH 7.9, 20\% glycerol, $0.3 \mathrm{M} \mathrm{NaCl}, 1.5 \mathrm{~mm} \mathrm{MgCl}_{2}, 0.2 \mathrm{~mm}$ EDTA, $1 \mathrm{~mm}$ dithiothreitol (DTT), $0.1 \mathrm{~mm} \beta$-glycerophosphate, $0.05 \mathrm{~mm}$ vanadate, $1 \mathrm{~mm}$ phenylmethylsulfonyl fluoride, and $1 \mu \mathrm{g} / \mathrm{ml}$ each of pepstatin A, leupeptin, and aprotinin. After extraction on ice for $30 \mathrm{~min}$, the samples were centrifuged at $16,000 \times g$ for $15 \mathrm{~min}$ at $4^{\circ} \mathrm{C}$. The supernatant containing nuclear proteins was transferred to a microfuge tube, an aliquot was removed for determination of the protein concentration (Bradford, 1976), and samples were stored at $-80^{\circ} \mathrm{C}$.

EMSAs were performed using a double-stranded 15 base pair oligonucleotide (5'-CTAGGGGGACTTTCC-3') containing the $\mathrm{NF} \kappa \mathrm{B}$ consensus sequence or an 18 base pair oligonucleotide (5'CTAGTGATGAGTCAGCCG-3') containing the AP-1 consensus sequence, which was radiolabeled as described previously (Unlap and Jope, 1995). For the binding reaction, the nuclear protein extract $(2 \mu \mathrm{g}$ for AP-1; $10 \mu \mathrm{g}$ for $\mathrm{NF} \kappa \mathrm{B}$ ) was incubated in a total volume of $20 \mu \mathrm{l}$ in binding buffer containing $20 \mathrm{~mm}$ HEPES, $\mathrm{pH} 7.9,4 \%$ glycerol, $1 \mathrm{~mm}$ $\mathrm{MgCl}_{2}, 50 \mathrm{~mm} \mathrm{KCl}, 0.5 \mathrm{~mm}$ DTT, $1 \mu \mathrm{g}$ poly (dI-dC), and $\sim 10,000 \mathrm{cpm}$ radiolabeled DNA for $30 \mathrm{~min}$ at $4^{\circ} \mathrm{C}$. Where indicated, reactions included 100 -fold excess unlabeled AP-1 or NF $\kappa$ B oligonucleotides, and supershift analyses were performed with antibodies to the Fos family of proteins
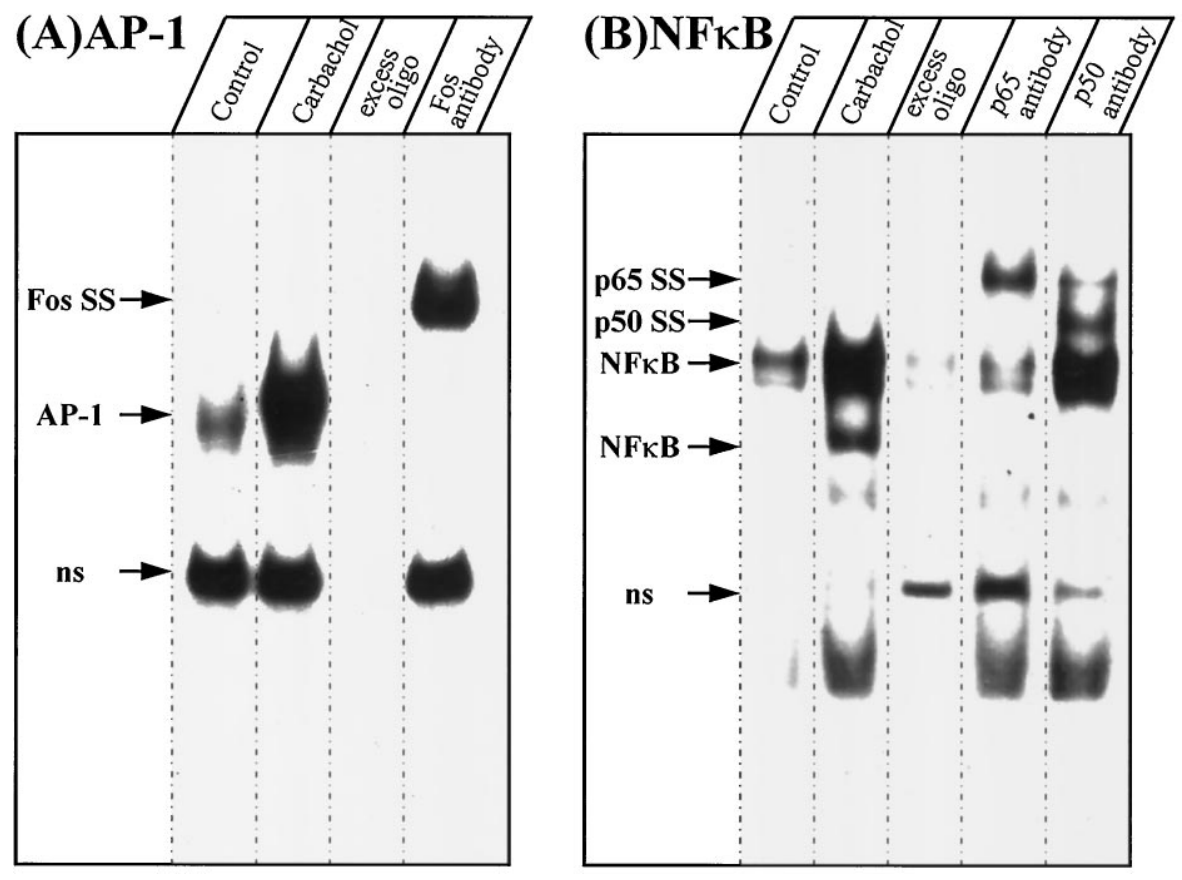

Figure 2. Carbachol-stimulated AP-1 and $\mathrm{NF} \kappa \mathrm{B}$ DNA binding activities. SH-SY5Y cells were treated without (Control) or with $1 \mathrm{~mm}$ carbachol for $1 \mathrm{hr}$, followed by EMSA measurements of AP-1 $(A)$ and $\mathrm{NF}_{\kappa} \mathrm{B}(B)$ in nuclear extracts. Arrows indicate the single AP-1 band and the two $\mathrm{NF} \kappa \mathrm{B}$ bands. Where indicated, reaction mixtures contained 100 -fold excess unlabeled AP-1 or $\mathrm{NF} \kappa \mathrm{B}$ oligonucleotides. Supershifted $(S S)$ bands are indicated in samples that were incubated with antibodies to the Fos family of proteins, p65 or p50. ns, Nonspecific. 
(A) AP-1

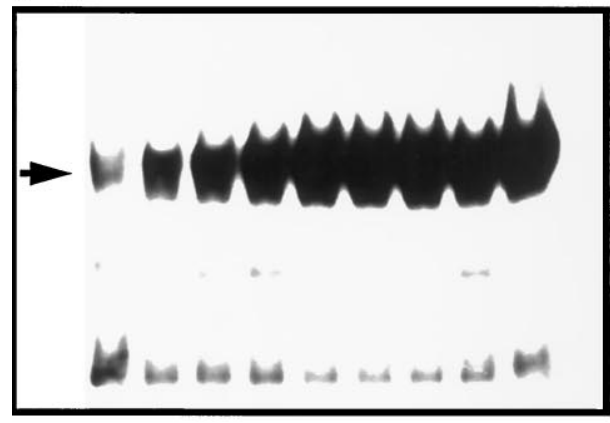

$\begin{array}{llllllllll}0 & 0.3 & 1 & 3 & 10 & 30 & 100 & 300 & 1000\end{array}$
(B) $\mathrm{NF} \kappa \mathrm{B}$

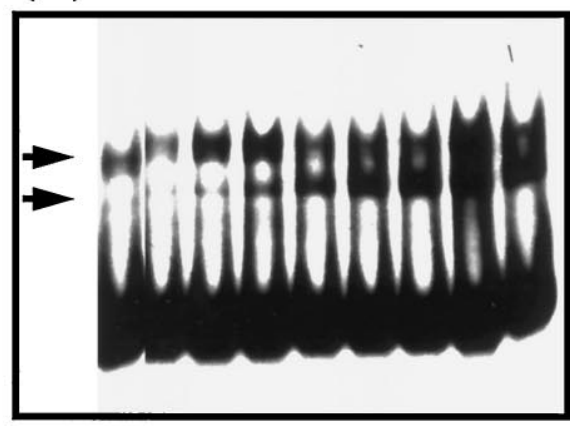

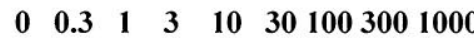

\section{CARBACHOL $(\mu \mathrm{M})$}

\section{CARBACHOL $(\mu \mathrm{M})$}

(C) AP-1

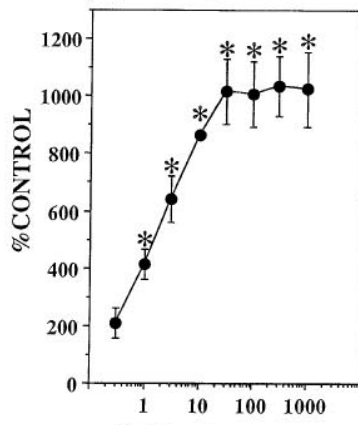

CARBACHOL $(\mu \mathrm{M})$
(D) NFkB

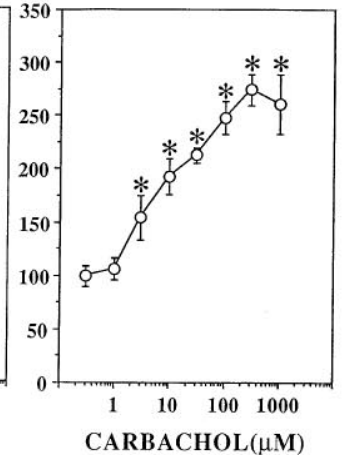

Figure 3. Carbachol concentration-dependent $(A-D)$ and time-dependent $(E)$ activation of AP-1 $(A, C)$ and NF $\kappa \mathrm{B}(B, D)$. SH-SY5Y cells were treated with $3 \times 10^{-7}$ to $10^{-3} \mathrm{M}$ carbachol $(A-D)$ for $1 \mathrm{hr}(n=3-4)$ or with $10^{-3} \mathrm{M}$ carbachol $(E)$ for $0.25-20 \mathrm{hr}(n=3-4)$. Cells were harvested, and $\mathrm{AP}-1$ and $\mathrm{NF} \kappa \mathrm{B}$ DNA binding activities were measured in nuclear extracts as described in Materials and Methods. Both bands of $\mathrm{NF} \kappa \mathrm{B}$ were measured together to calculate overall stimulation caused by carbachol. Values are given as the percent of untreated cells (controls). Mean \pm SEM. ${ }^{*} p<$ 0.05 compared with control values (no carbachol) (ANOVA with a post hoc Dunnett multiple comparisons test).

(kindly provided by Dr. M. J. Iadarola, National Institutes of Health), p65 (Rockland, Gilbertsville, PA), or p50 (Rockland). DNA-protein complexes were resolved on a preelectrophoresed $6 \%$ nondenaturing polyacrylamide gel in $0.25 \times$ TBE $(22.3 \mathrm{~mm}$ Tris, $22.3 \mathrm{~mm}$ boric acid, and 0.5 mM EDTA) at $4^{\circ} \mathrm{C}$ for $1.5 \mathrm{hr}$ at $150 \mathrm{~V}$. Subsequently, the gel was dried under vacuum and exposed to film. The amount of DNA-protein complex present was analyzed using a Phosphor Imager (Molecular Dynamics, Sunnyvale, CA), and specific bands were identified by displacement of radioactivity with excess unlabeled oligonucleotides and supershift analyses. Data from treated cells were compared with controls using ANOVA.

Protein kinase $C$ - $\alpha$ translocation. SH-SY5Y cells were treated with phorbol 12-myristate 13-acetate (PMA) as indicated in Results, followed by two washes with ice-cold PBS. Cells were harvested in TE buffer (10 mM Tris-Cl, pH 7.4, and 1 mM EDTA), sonicated on ice for $15 \mathrm{sec}$, and centrifuged at $16,000 \times g$ for $30 \mathrm{~min}$ at $4^{\circ} \mathrm{C}$. The pellets were washed with TE buffer, resuspended by sonication, and used as the membrane fractions. The supernatants were centrifuged at $16,000 \times g$ for $30 \mathrm{~min}$ at $4^{\circ} \mathrm{C}$, and the resultant supernatants were used as the cytosol fractions. Protein concentrations of both fractions were measured using the Bradford

(E) Time-Dependence

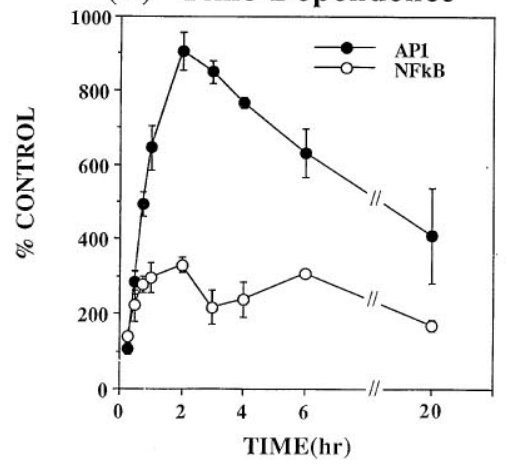

protein assay (1976), and aliquots were solubilized in Laemmli sample buffer (Laemmli, 1970) by boiling for 2 min. Proteins $(25 \mu \mathrm{g})$ from the membrane and cytosol fractions were resolved in 9\% SDS-polyacrylamide gels, transferred to nitrocellulose membranes, and probed with an antibody to protein kinase C- $\alpha$ (Life Technologies, Gaithersburg, MD). Immunoreactive bands were analyzed by densitometry, and statistical significance was determined using the paired Student's $t$ test.

Phosphoinositide hydrolysis. SH-SY5Y cells in $100 \mathrm{~mm}$ culture dishes were prelabeled with $75 \mu \mathrm{Ci} / \mathrm{ml}\left[{ }^{3} \mathrm{H}\right.$ ]inositol (American Radiolabeled Chemicals, St. Louis, MO) for $2 \mathrm{~d}$ at $37^{\circ} \mathrm{C}$ in RPMI medium containing $5 \%$ fetal clone II, $10 \%$ horse serum, $2 \mathrm{~mm}$ L-glutamine, $100 \mathrm{U} / \mathrm{ml}$ penicillin, and $100 \mu \mathrm{g} / \mathrm{ml}$ streptomycin. Labeled cells were washed and suspended in Krebs'-bicarbonate-HEPES buffer (30 mM HEPES, pH 7.4, $122 \mathrm{~mm} \mathrm{NaCl}, 3.6 \mathrm{~mm} \mathrm{NaHCO}, 1.2 \mathrm{~mm} \mathrm{MgCl}_{2}, 5 \mathrm{~mm} \mathrm{KCl}, 1.3 \mathrm{~mm}$ $\mathrm{CaCl}_{2}, 11 \mathrm{~mm}$ glucose $)$ and washed twice. Suspended cells ( $10^{5}$ cells in 0.5 $\mathrm{ml}$ ) were incubated at $37^{\circ} \mathrm{C}$ for $10 \mathrm{~min}$ with or without the addition of $\mathrm{H}_{2} \mathrm{O}_{2}$ followed by incubation with $1 \mathrm{~mm}$ carbachol, $20 \mathrm{~mm} \mathrm{NaF}$ (with 10 $\mu \mathrm{M} \mathrm{AlCl}_{3}$ ), or $50 \mu \mathrm{M}$ ionomycin (with $2.2 \mathrm{mM} \mathrm{CaCl}_{2}$ ) for $30 \mathrm{~min}$. The reaction was stopped by adding $1.7 \mathrm{ml}$ of $\mathrm{CHCl}_{3}: \mathrm{MeOH}: 12 \mathrm{~N} \mathrm{HCl}(1: 2$ : 0.01). Inositol monophosphate, inositol, and lipids were fractionated as 

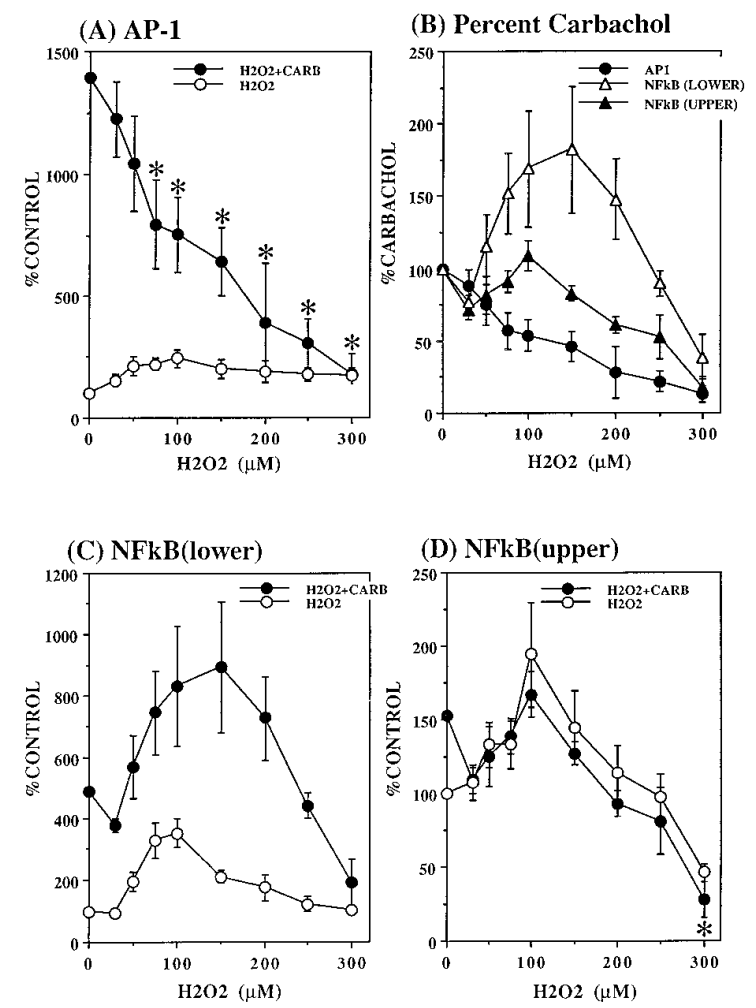

Figure 4. Modulation by $\mathrm{H}_{2} \mathrm{O}_{2}$ of carbachol-stimulated AP-1 $(A, B)$ and $\mathrm{NF} \kappa \mathrm{B}(B-D)$ DNA binding. SH-SY5Y cells were incubated with the indicated concentration $(30-300 \mu \mathrm{M})$ of $\mathrm{H}_{2} \mathrm{O}_{2}$ for $1 \mathrm{hr}$ followed by addition of $1 \mathrm{~mm}$ carbachol for an additional hour. Cells were harvested, and AP-1 and NF $\kappa$ B DNA binding activities were measured as described in Materials and Methods. Values in $A, C$, and $D$ are given as the percent of controls that were not exposed to $\mathrm{H}_{2} \mathrm{O}_{2}$, or, in $B$, as the percent of values obtained with carbachol in the absence of $\mathrm{H}_{2} \mathrm{O}_{2}$. Mean \pm SEM $(n=3-7) .{ }^{*} p<0.05$ compared with carbachol stimulation in the absence of $\mathrm{H}_{2} \mathrm{O}_{2}$ (ANOVA with a post hoc Dunnett multiple comparisons test).

described previously (Jope and Li, 1989). Radioactivity was measured in each fraction, and data were analyzed using ANOVA with a post hoc Bonferroni test.

\section{RESULTS}

Exposure of SH-SY5Y neuroblastoma cells to 30-300 $\mu \mathrm{M} \mathrm{H}_{2} \mathrm{O}_{2}$ for $2 \mathrm{hr}$ caused concentration-dependent changes in AP-1 and NF $\kappa$ B DNA binding, which resulted in bell-shaped curves (Fig. 1). AP-1 was stimulated by low concentrations of $\mathrm{H}_{2} \mathrm{O}_{2}$ to a maximum of $\sim 250 \%$ of control with $100 \mu \mathrm{M} \mathrm{H}_{2} \mathrm{O}_{2}$, followed by a concentration-dependent diminution in the stimulation of AP-1 to a minimum of $170 \%$ of control with $300 \mu \mathrm{M} \mathrm{H} \mathrm{H}_{2} \mathrm{O}_{2}$. Two bands of $\mathrm{NF} \kappa \mathrm{B}$ DNA binding activity were apparent in the EMSA, designated as upper and lower to indicate the bands with slower and faster mobilities, respectively. NF $\mathrm{B}$ DNA binding activity responded to $\mathrm{H}_{2} \mathrm{O}_{2}$ in a bell-shaped, concentration-dependent manner similar to that observed with AP-1. Low concentrations of $\mathrm{H}_{2} \mathrm{O}_{2}$ increased $\mathrm{NF} \kappa \mathrm{B}$ to maximums of $\sim 350$ and $200 \%$ of control for the lower and upper NF $\kappa \mathrm{B}$ bands, respectively, achieved with $100 \mu \mathrm{M} \mathrm{H} \mathrm{H}_{2} \mathrm{O}_{2}$, followed by decreased stimulation with higher concentrations of $\mathrm{H}_{2} \mathrm{O}_{2}$ and reduction to below control levels of the upper band with $300 \mu \mathrm{M} \mathrm{H}_{2} \mathrm{O}_{2}$.

Treatment of SH-SY5Y cells with carbachol increased AP-1 and NF $\kappa$ B DNA binding activities (Fig. 2). AP-1 was detected as a single band in the EMSA, and it was virtually eliminated by inclusion of excess unlabeled AP-1 oligimer in the binding reac-

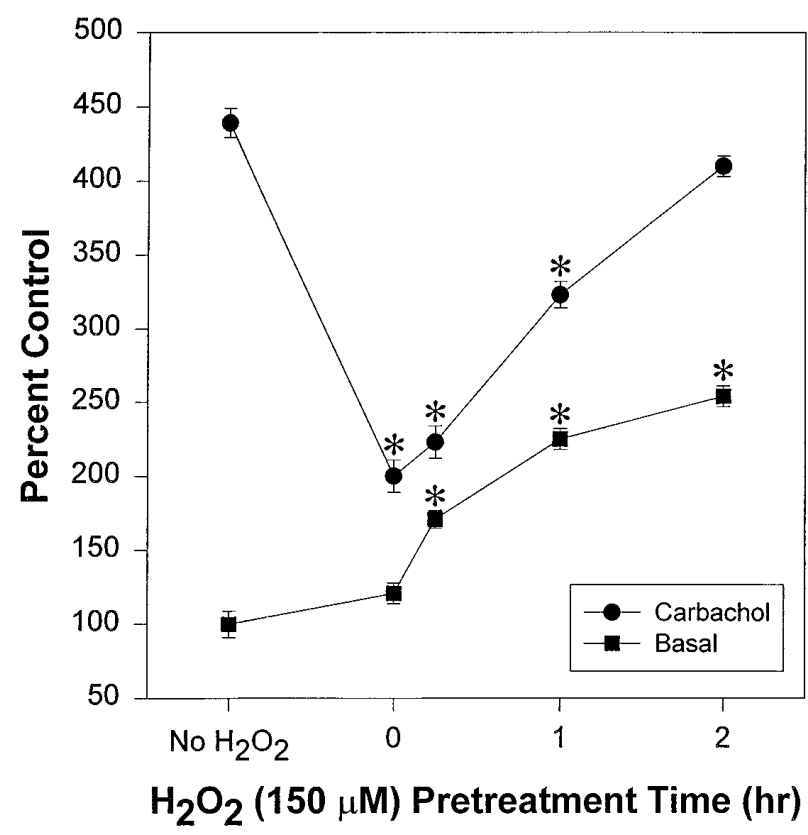

Figure 5. Time dependence of the inhibition by $\mathrm{H}_{2} \mathrm{O}_{2}$ of carbacholstimulated AP-1. SH-SY5Y cells were incubated with $150 \mu \mathrm{M} \mathrm{H}_{2} \mathrm{O}_{2}$ for $0-2 \mathrm{hr}$ before the addition of $1 \mathrm{~mm}$ carbachol. After $1 \mathrm{hr}$ exposure to carbachol, AP-1 DNA binding activity was measured in nuclear extracts as described in Materials and Methods. Values are given as the percent of AP-1 in untreated cells. Mean \pm SEM. ${ }^{*} p<0.05$ compared with control values for basal or with carbachol alone (no $\mathrm{H}_{2} \mathrm{O}_{2}$ ) (ANOVA).

tion. Incubation with an antibody to the Fos family of proteins supershifted the AP-1 band to one with slower mobility. NF $\kappa \mathrm{B}$ was detected as two major bands that were increased after treatment of the cells with carbachol, and the top one sometimes resolved into a doublet. These bands were reduced in the presence of excess unlabeled $\mathrm{NF} \kappa \mathrm{B}$ oligimer. Incubation of nuclear extracts with an antibody to p65 reduced the intensity of both $\mathrm{NF} \kappa \mathrm{B}$ bands and produced a supershifted band with slower mobility, and anti-p50 reduced the intensity of the lower $\mathrm{NF} \kappa \mathrm{B}$ band and two supershifted bands appeared.

Carbachol induced concentration-dependent and timedependent induction of AP-1 and NF $\kappa \mathrm{B}$ DNA binding activities in SH-SY5Y cells (Fig. 3). AP-1 was increased maximally to $1000 \%$ of control by a $2 \mathrm{hr}$ treatment with $30 \mu \mathrm{M}$ carbachol with an $\mathrm{EC}_{50}$ of $\sim 2 \mu \mathrm{M}$ carbachol. NF $\kappa \mathrm{B}$ DNA binding (total of both bands) reached a maximum increase that was almost $300 \%$ of control with $300 \mu \mathrm{M}$ carbachol, and the $\mathrm{EC}_{50}$ of carbachol was $\sim 20 \mu \mathrm{M}$. Carbachol $(1 \mathrm{mM})$ induced rapid increases in both transcription factors, which reached peak levels after $2 \mathrm{hr}$ of treatment. Afterward, AP-1 decreased relatively steadily over time, whereas $\mathrm{NF} \kappa \mathrm{B}$ consistently rebounded after an initial decrease, followed by a decline at $20 \mathrm{hr}$.

Although carbachol and $\mathrm{H}_{2} \mathrm{O}_{2}$ each individually stimulated AP-1 DNA binding activity, treatment with $\mathrm{H}_{2} \mathrm{O}_{2}$ inhibited carbachol-induced AP-1 (Fig. 4A) concentration dependently. The responses to carbachol in the presence of the lower $\mathrm{H}_{2} \mathrm{O}_{2}$ concentrations were especially remarkable because $\mathrm{H}_{2} \mathrm{O}_{2}$ alone stimulated AP-1 to values up to $250 \%$ of control (with $100 \mu \mathrm{M}$ $\mathrm{H}_{2} \mathrm{O}_{2}$ ), whereas the stimulation by carbachol of AP-1 was concentration dependently decreased by $\mathrm{H}_{2} \mathrm{O}_{2}$, with an almost $50 \%$ reduction in the response to carbachol attained with $100 \mu \mathrm{M}$ $\mathrm{H}_{2} \mathrm{O}_{2}$. This represents a conservative estimate of the $\mathrm{H}_{2} \mathrm{O}_{2}$ - 


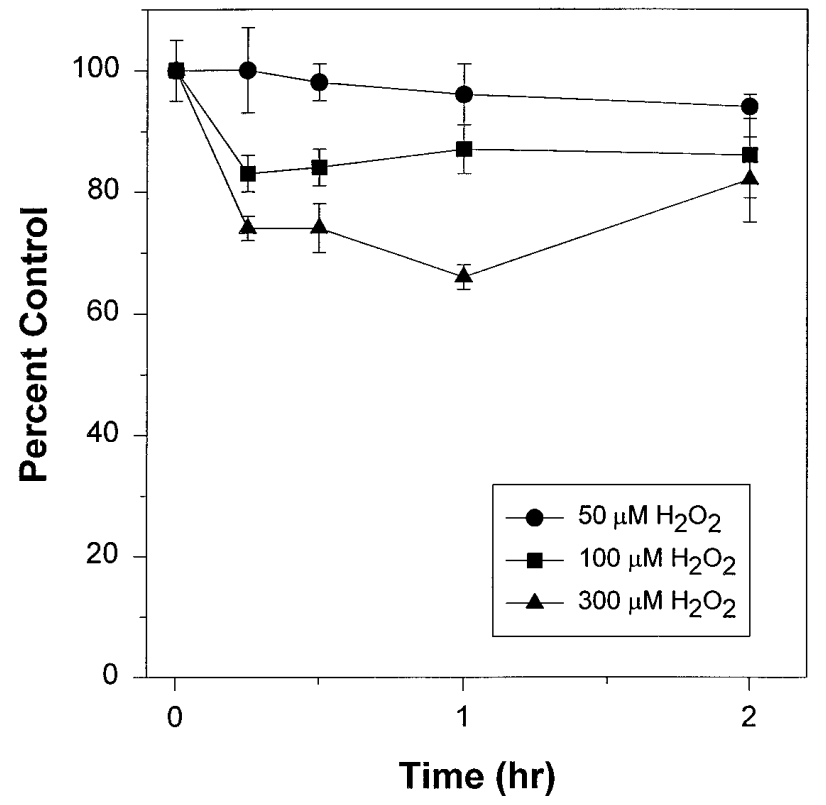

Figure 6. MTT reduction in SH-SY5Y cells. Cells were incubated with 50,100 , or $300 \mu \mathrm{M} \mathrm{H}_{2} \mathrm{O}_{2}$ for $15,30,60$, or 120 min followed by measurement of MTT reduction as described in Materials and Methods. Data are expressed as the percent of controls that were not exposed to $\mathrm{H}_{2} \mathrm{O}_{2}$. Mean $\pm \operatorname{SEM}(n=4)$.

induced inhibition of the response to carbachol because a portion of the AP-1 stimulation in the presence of $\mathrm{H}_{2} \mathrm{O}_{2}$ plus carbachol is contributed by $\mathrm{H}_{2} \mathrm{O}_{2}$. Higher concentrations of $\mathrm{H}_{2} \mathrm{O}_{2}$ further decreased carbachol-stimulated AP-1, and $300 \mu \mathrm{M} \mathrm{H}_{2} \mathrm{O}_{2}$ eliminated stimulation by carbachol. These inhibitory effects of pretreatment with $\mathrm{H}_{2} \mathrm{O}_{2}$ on the response to carbachol are shown in Figure $3 B$, where values are expressed as the percent of the response to carbachol in the absence of $\mathrm{H}_{2} \mathrm{O}_{2}$.

The interactions of carbachol and $\mathrm{H}_{2} \mathrm{O}_{2}$ on the stimulation of
$\mathrm{NF} \kappa \mathrm{B}$ were quite distinct from those on AP-1 (Fig. 4). For the lower $\mathrm{NF} \kappa \mathrm{B}$ band, the effects of carbachol and $\mathrm{H}_{2} \mathrm{O}_{2}$ were approximately additive of the individual responses. Thus, $\mathrm{H}_{2} \mathrm{O}_{2}$ alone maximally increased $\mathrm{NF} \kappa \mathrm{B}$ (lower band) by $350 \%$ at a concentration of $100 \mu \mathrm{M}$, and $100 \mu \mathrm{M} \mathrm{H} \mathrm{H}_{2} \mathrm{O}_{2}$ increased the response to carbachol by $>300 \%$. Only at the highest concentration of $\mathrm{H}_{2} \mathrm{O}_{2}(300 \mu \mathrm{M})$ was there clear inhibition of the stimulation by carbachol. The response of the upper band of $\mathrm{NF} \kappa \mathrm{B}$ to $\mathrm{H}_{2} \mathrm{O}_{2}$ plus carbachol was more difficult to discern because of the relatively small stimulation produced by each agent individually. There appeared to be a slight inhibitory effect of $\mathrm{H}_{2} \mathrm{O}_{2}$ on the response to carbachol because the individual responses were less than additive, but this was not clearly evident except with the highest concentrations of $\mathrm{H}_{2} \mathrm{O}_{2}$.

Examination of the pretreatment time-dependence of the inhibition by $150 \mu \mathrm{M} \mathrm{H}_{2} \mathrm{O}_{2}$ of carbachol-induced AP-1 revealed that it was rapid and reversible. The data in Figure 5 show that the greatest inhibition of carbachol-stimulated AP-1 occurred when cells were exposed to $\mathrm{H}_{2} \mathrm{O}_{2}$ immediately before the addition of carbachol. Preincubation with $\mathrm{H}_{2} \mathrm{O}_{2}$ lessened its inhibitory effect in a time-dependent manner, with clear attenuation of the inhibition occurring with a $2 \mathrm{hr} \mathrm{H}_{2} \mathrm{O}_{2}$ preincubation before addition of carbachol. Concurrently, there was a time-dependent increase in AP-1 induced by $\mathrm{H}_{2} \mathrm{O}_{2}$ in the absence of carbachol.

To measure the magnitude of the altered oxidation state caused by $\mathrm{H}_{2} \mathrm{O}_{2}$, the concentration- and time-dependent effects of $\mathrm{H}_{2} \mathrm{O}_{2}$ on SH-SY5Y cells were assessed using the MTT assay, which measures cellular redox changes resulting from impaired mitochondrial enzyme function. Exposure of cells to $50 \mu \mathrm{M} \mathrm{H}_{2} \mathrm{O}_{2}$ resulted in a $10 \%$ decrease in MTT reduction, and decreases of $\sim 20$ and $30 \%$ were obtained after incubation with 100 and $300 \mu \mathrm{M}$ $\mathrm{H}_{2} \mathrm{O}_{2}$, respectively (Fig. 6).

To test whether $\mathrm{H}_{2} \mathrm{O}_{2}$ could impair the stimulation of AP-1 or $\mathrm{NF} \kappa \mathrm{B}$ DNA binding by reducing the activation of protein kinase $\mathrm{C}$, two strategies were employed using PMA to directly activate protein kinase $C$. First, the effects of $\mathrm{H}_{2} \mathrm{O}_{2}$ on AP-1
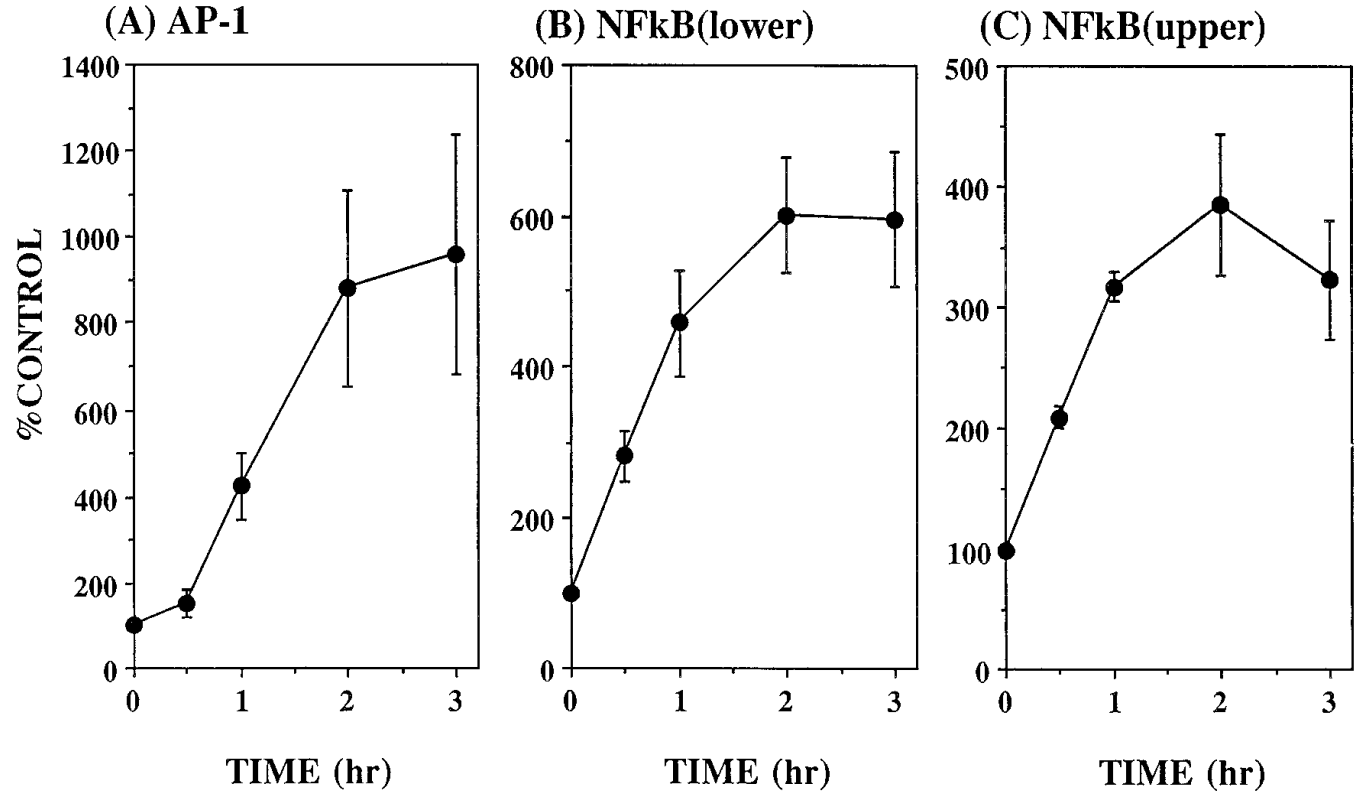

Figure 7. Time-dependent activation of AP-1 $(A)$ and NF $\kappa$ B $(B, C)$ by PMA. SH-SY5Y cells were incubated with $1 \mu \mathrm{M}$ PMA, and AP-1 and NF $\kappa \mathrm{B}$ DNA binding activities were measured in nuclear extracts as described in Materials and Methods. Values are given as the percent of controls that were not exposed to PMA. Mean $\pm \operatorname{SEM}(n=4)$. 
(A) AP-1

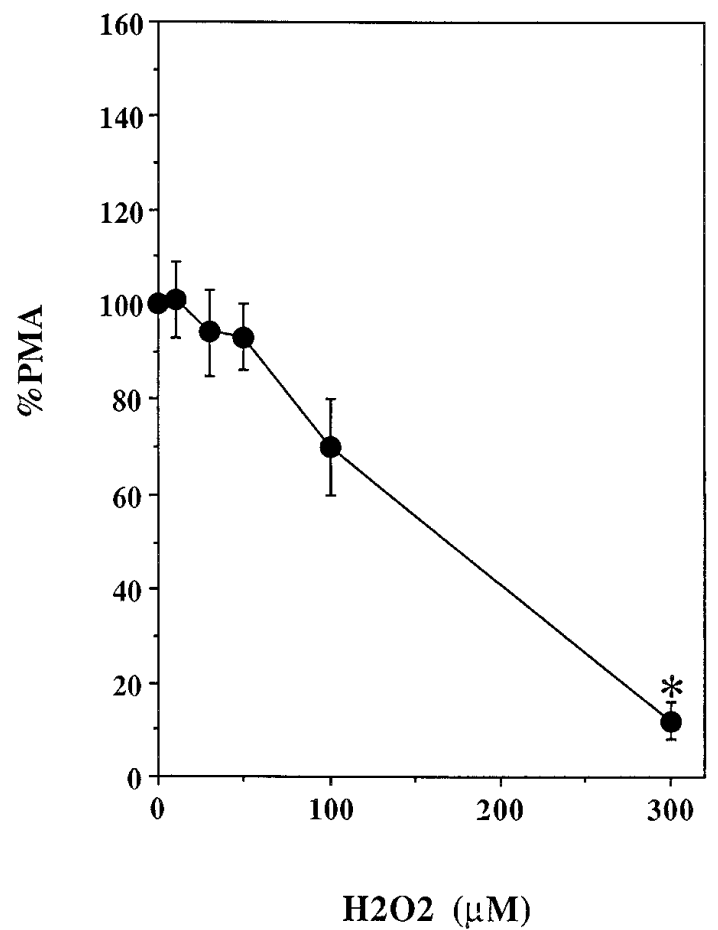

(B) NFkB

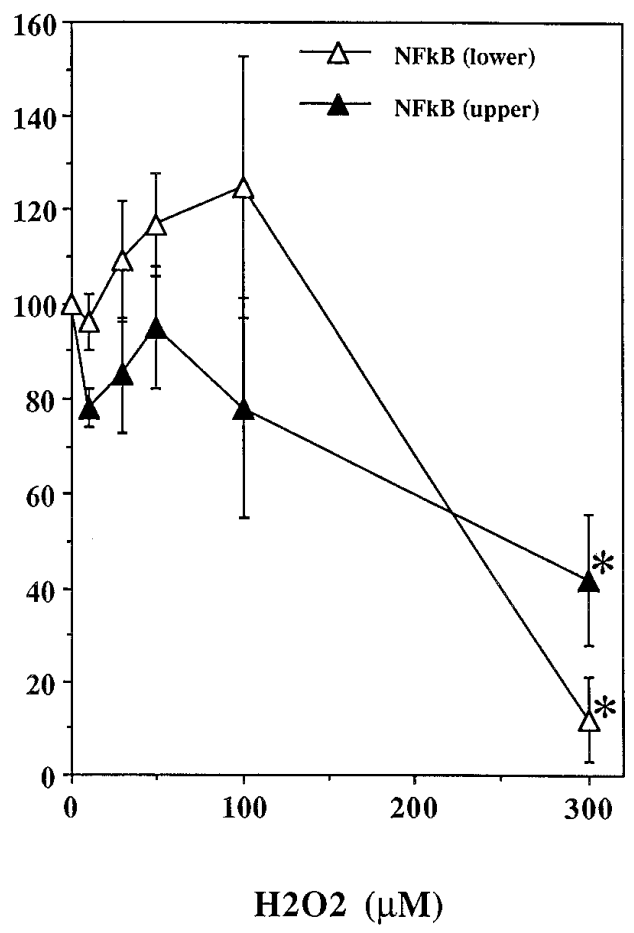

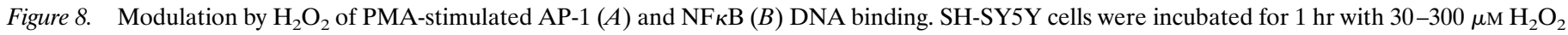

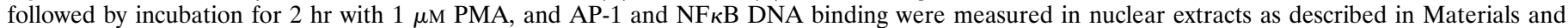

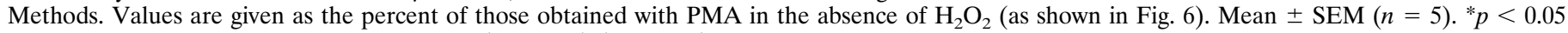
compared with cells treated with PMA alone (no $\mathrm{H}_{2} \mathrm{O}_{2}$ ) (ANOVA).

and $\mathrm{NF} \kappa \mathrm{B}$ stimulated by PMA were measured, and second, the effect of $\mathrm{H}_{2} \mathrm{O}_{2}$ on PMA-induced membrane translocation of protein kinase $\mathrm{C}-\alpha$ was measured. PMA $(1 \mu \mathrm{M})$ induced timedependent increases in each of the transcription factors, with AP-1 being activated to the greatest extent and the upper $\mathrm{NF} \kappa \mathrm{B}$ band the least (Fig. 7). Only at a concentration of 300 $\mu \mathrm{M}$ did $\mathrm{H}_{2} \mathrm{O}_{2}$ consistently inhibit PMA-induced activation of AP-1 or NF $\kappa$ B (Fig. 8).

In the second series of experiments designed to measure the interactions of $\mathrm{H}_{2} \mathrm{O}_{2}$ and protein kinase $\mathrm{C}$, measurements were made of the modulation by $\mathrm{H}_{2} \mathrm{O}_{2}$ of the PMA-induced translocation to the membrane of protein kinase $\mathrm{C}-\alpha$, the major subtype expressed in these cells. PMA $(0.1 \mu \mathrm{M})$ induced a time-dependent translocation of protein kinase $\mathrm{C}-\alpha$ from the cytosol to the membrane (Fig. 9). The PMA-induced translocation of protein kinase C- $\alpha$ was inhibited by only $40 \%$ with $300 \mu \mathrm{M} \mathrm{H}_{2} \mathrm{O}_{2}$ (Fig. 10). These findings indicate that inhibition of carbachol-stimulated AP-1 activation by low concentrations of $\mathrm{H}_{2} \mathrm{O}_{2}$ was unlikely to be attributable to impaired activation of protein kinase $\mathrm{C}$. However, because $300 \mu \mathrm{M} \mathrm{H}_{2} \mathrm{O}_{2}$ inhibited PMA-induced protein kinase $\mathrm{C}$ activation, this mechanism likely contributes to the inhibition by $300 \mu \mathrm{M} \mathrm{H} \mathrm{H}_{2} \mathrm{O}_{2}$ of AP-1 and $\mathrm{NF} \kappa \mathrm{B}$ activation induced by carbachol and by PMA.

To determine whether $\mathrm{H}_{2} \mathrm{O}_{2}$ modulated signaling induced by carbachol at a site upstream from protein kinase $\mathrm{C}$ activation, carbachol-induced phosphoinositide hydrolysis was measured. SH-SY5Y cells were prelabeled with $\left[{ }^{3} \mathrm{H}\right]$ inositol, and carbacholinduced $\left[{ }^{3} \mathrm{H}\right]$ phosphoinositide hydrolysis was measured with or without a 10 min preexposure to $30-500 \mu \mathrm{M} \mathrm{H}_{2} \mathrm{O}_{2}$. Figure $11 A$ shows that $\mathrm{H}_{2} \mathrm{O}_{2}$ inhibited carbachol-induced phosphoinositide hydrolysis concentration dependently. There was a significant correlation between the $\mathrm{H}_{2} \mathrm{O}_{2}$ concentration-dependent inhibition of carbachol-stimulated AP-1 and $\left[{ }^{3} \mathrm{H}\right]$ phosphoinositide hydrolysis $(r=0.95 ; p<0.001)$.

To identify the site of the phosphoinositide signal transduction system that was susceptible to inhibition by $\mathrm{H}_{2} \mathrm{O}_{2},\left[{ }^{3} \mathrm{H}\right]$ phosphoinositide hydrolysis was measured using $\mathrm{NaF}$ to activate G-proteins coupled to phospholipase C (Jope, 1988) or using the calcium ionophore ionomycin to directly activate phospholipase $\mathrm{C}$ (Fisher et al., 1989). $\mathrm{H}_{2} \mathrm{O}_{2}$ treatment inhibited NaF-induced $\left[{ }^{3} \mathrm{H}\right]$ phosphoinositide hydrolysis (Fig. $11 B$ ) with a concentration dependence similar to that observed with carbachol stimulation, except at the higher concentrations of $\mathrm{H}_{2} \mathrm{O}_{2}$ where the response to $\mathrm{NaF}$ was inhibited less than was carbachol stimulation (Fig. $11 D$ ). Incubation of SH-SY5Y cells with $\mathrm{H}_{2} \mathrm{O}_{2}$ did not alter the level of $\mathrm{G} \alpha \mathrm{q} / 11$ in cell membranes detected by quantitative immunoblots (data not shown), indicating that the function, rather than the level, of $\mathrm{G} \alpha \mathrm{q} / 11$ was impaired by $\mathrm{H}_{2} \mathrm{O}_{2}$. Ionomycinstimulated $\left[{ }^{3} \mathrm{H}\right]$ phosphoinositide hydrolysis was unaffected by $\mathrm{H}_{2} \mathrm{O}_{2}$ (Fig. $11 C$ ). Thus, calcium-activated phospholipase $\mathrm{C}$ and phosphoinositide substrates were impervious to treatment with $\mathrm{H}_{2} \mathrm{O}_{2}$, whereas $\mathrm{G}$-protein activation was impaired.

\section{DISCUSSION}

The primary objective of this study was to determine whether oxidative stress influenced cholinergic muscarinic receptorinduced signaling processes in neuronal cells. Oxidative stress caused by $\mathrm{H}_{2} \mathrm{O}_{2}$ was found to markedly impair carbachol-induced AP-1 DNA binding, an effect that was apparently attributable to impaired activation of the phosphoinositide signal transduction 
(A)

$\mathbf{M}$

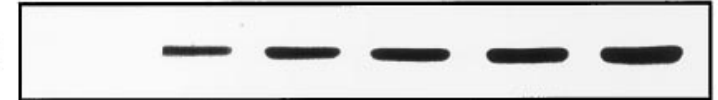

C

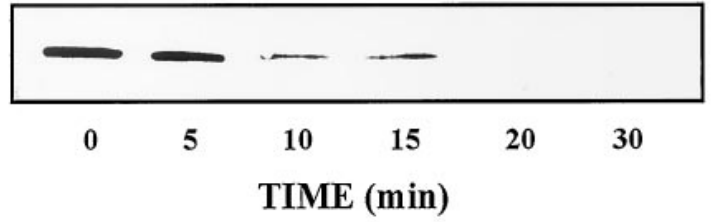

(B)

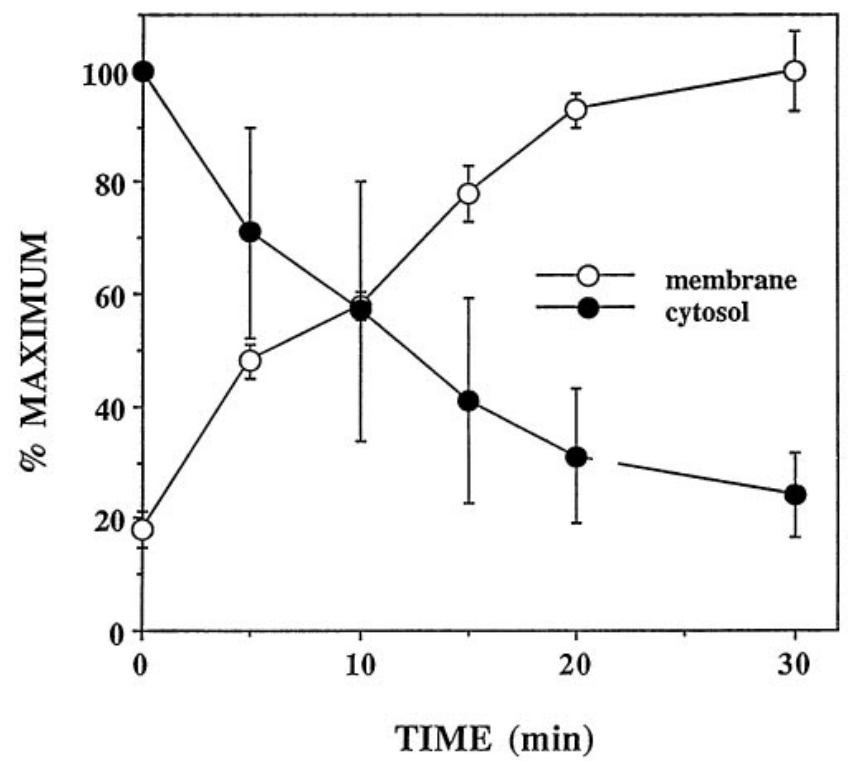

Figure 9. PMA-induced translocation of protein kinase C- $\alpha . A, \mathrm{SH}-$ SY5Y cells were incubated with $0.1 \mu \mathrm{M}$ PMA for $5,10,15,20$, and $30 \mathrm{~min}$, membrane $(M)$ and cytosolic $(C)$ fractions were prepared, and protein kinase $\mathrm{C}-\alpha$ was measured by immunoblotting as described in Materials and Methods. $B$, The immunoblots of membrane and cytosol protein kinase $\mathrm{C}-\alpha$ were quantitated by densitometry, and data were calculated as percentage of maximal protein kinase $\mathrm{C}-\alpha$ (30 min PMA treatment for the membrane fraction and no PMA treatment for the cytosol fraction). $n=$ 3 for both membrane and cytosol protein kinase C- $\alpha$ using samples from three individual experiments.

system, whereas carbachol-induced $\mathrm{NF} \kappa \mathrm{B}$ DNA binding was resistant to oxidative stress except at the highest concentration of $\mathrm{H}_{2} \mathrm{O}_{2}$ tested $(300 \mu \mathrm{M})$, where inhibition was associated with reduced activation of protein kinase $\mathrm{C}$. Thus, not only was neuronal carbachol-induced signaling found to be susceptible to inhibition by oxidative stress, but two downstream responses to carbachol, activation of AP-1 and NF $\kappa$ B DNA binding, were revealed to be differentially sensitive to impairment by $\mathrm{H}_{2} \mathrm{O}_{2}$.

It was interesting to find that, whereas individually, carbachol and $\mathrm{H}_{2} \mathrm{O}_{2}$ each increased AP-1 DNA binding in SH-SY5Y cells, coincident exposure to both agents impaired this response. Oxidative stress has been reported many times previously, and in a wide variety of cell types, to increase AP-1, as well as NF $\kappa \mathrm{B}$ DNA binding (for review, see Karin and Smeal, 1992; Siebenlist et al., 1994). These effects of oxidative stress, in this case caused by $\mathrm{H}_{2} \mathrm{O}_{2}$, also were observed in SH-SY5Y cells, with $100 \mu \mathrm{M} \mathrm{H}_{2} \mathrm{O}_{2}$ causing a maximal stimulation (to $250 \%$ of basal) of AP-1. Thus, it is highly unlikely that inhibition by $\mathrm{H}_{2} \mathrm{O}_{2}$ of carbachol-induced

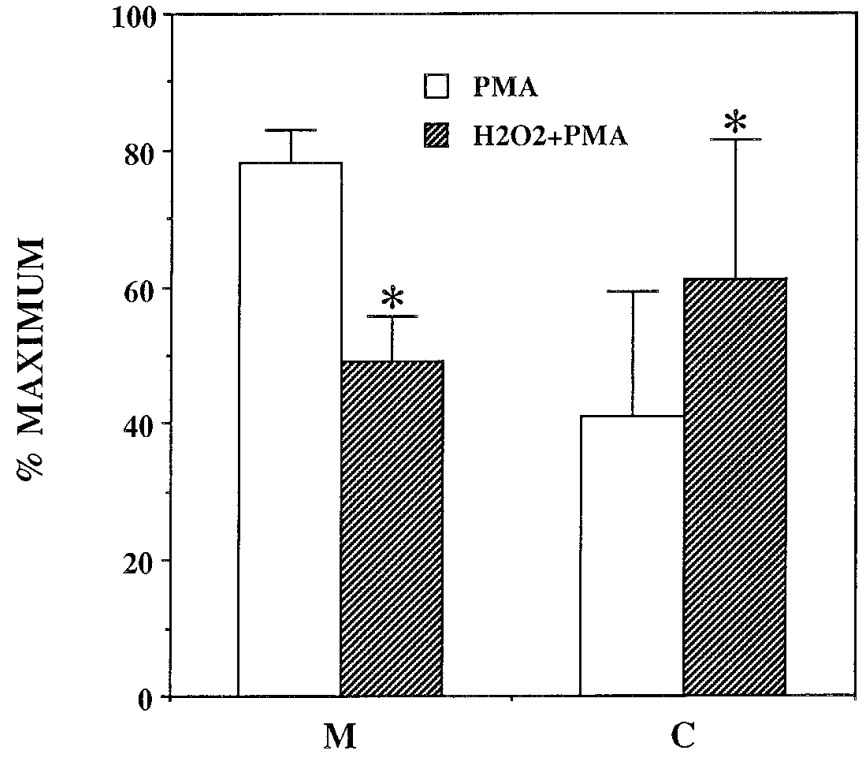

Figure 10. Inhibition by $\mathrm{H}_{2} \mathrm{O}_{2}$ of PMA-induced translocation of protein kinase C- $\alpha$. SH-SY5Y cells were incubated with $300 \mu \mathrm{M} \mathrm{H} \mathrm{H}_{2} \mathrm{O}_{2}$ for $45 \mathrm{~min}$ followed by the addition of $0.1 \mu \mathrm{M}$ PMA. After $15 \mathrm{~min}$, protein kinase C- $\alpha$ was measured in the membrane $(M)$ and cytosol $(C)$ fractions. Data were calculated as the percent of maximal protein kinase C (30 min PMA treatment for the membrane fraction and no PMA treatment for the cytosol fraction). Mean $\pm \operatorname{SEM}(n=3) .{ }^{*} p<0.05$ compared with cells not exposed to $\mathrm{H}_{2} \mathrm{O}_{2}$ (paired $t$ test).

AP-1 was attributable to a direct inhibitory effect of $\mathrm{H}_{2} \mathrm{O}_{2}$ on AP-1 constituent proteins or DNA binding (because $\mathrm{H}_{2} \mathrm{O}_{2}$ alone was stimulatory); it is more likely that a site upstream in the cholinergic signaling cascade was impaired by $\mathrm{H}_{2} \mathrm{O}_{2}$. Inhibition of protein kinase $\mathrm{C}$ activation may have contributed to the maximal impairment of AP-1 that was induced by $300 \mu \mathrm{M} \mathrm{H} \mathrm{H}_{2} \mathrm{O}_{2}$, because this treatment reduced PMA-induced AP-1 activation and protein kinase $\mathrm{C}$ translocation. (Unfortunately, carbachol-induced translocation of protein kinase $\mathrm{C}$ to the membrane was not detectable in these cells.) However, the inhibitory effects of lower concentrations of $\mathrm{H}_{2} \mathrm{O}_{2}$ on carbachol-induced AP-1 indicated that an earlier response to carbachol, before protein kinase $\mathrm{C}$ activation, was susceptible to inhibition by $\mathrm{H}_{2} \mathrm{O}_{2}$. Measurements of phosphoinositide hydrolysis stimulated by carbachol revealed a severe inhibition with low concentrations of $\mathrm{H}_{2} \mathrm{O}_{2}$, and the magnitude of the inhibition correlated closely $(r=0.95)$ with the $\mathrm{H}_{2} \mathrm{O}_{2}$ concentration-dependent inhibition of carbachol-induced AP-1. Thus, it appears most likely that diminution of carbacholstimulated AP-1 activation caused by oxidative stress induced by $\mathrm{H}_{2} \mathrm{O}_{2}$ primarily resulted from inhibition of carbachol-induced phosphoinositide hydrolysis.

The site of action of $\mathrm{H}_{2} \mathrm{O}_{2}$ that accounted for the inhibition of phosphoinositide hydrolysis appeared not to involve changes in phospholipase $\mathrm{C}$ or the inositol phospholipids, because ionomycin-induced phospholipase $\mathrm{C}$ activation was unaltered by $\mathrm{H}_{2} \mathrm{O}_{2}$. However, because G-protein-activated (by NaF), as well as carbachol-stimulated, phosphoinositide hydrolysis was impaired by $\mathrm{H}_{2} \mathrm{O}_{2}$, it appears that the G-protein is a likely target of the inhibitory actions of $\mathrm{H}_{2} \mathrm{O}_{2}$. Further studies will be required to identify the mechanism by which $\mathrm{H}_{2} \mathrm{O}_{2}$ impairs G-protein function. However, it is known that blocking sulfhydryl groups on the G-protein $\alpha$-subunit impairs its activation of phospholipase $\mathrm{C}$ (Jope et al., 1987), so this represents one likely candidate site for 
(A) CARBACHOL

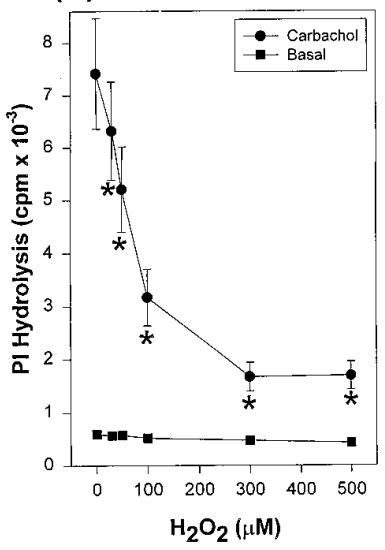

(C) IONOMYCIN

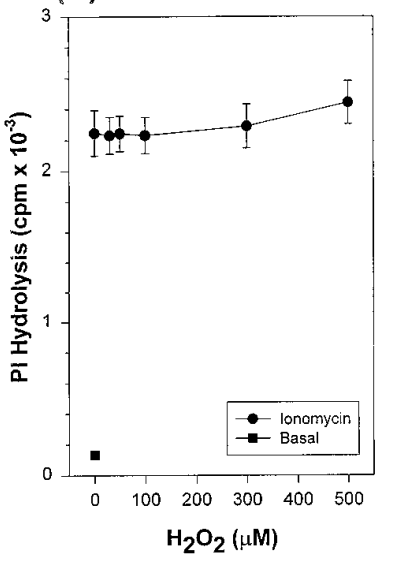

(B) $\mathrm{NaF}$

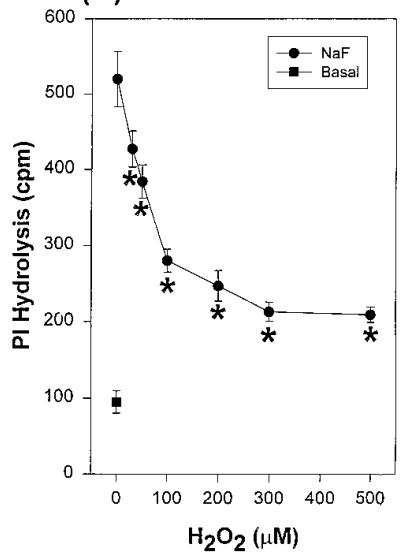

(D)PERCENT CONTROL

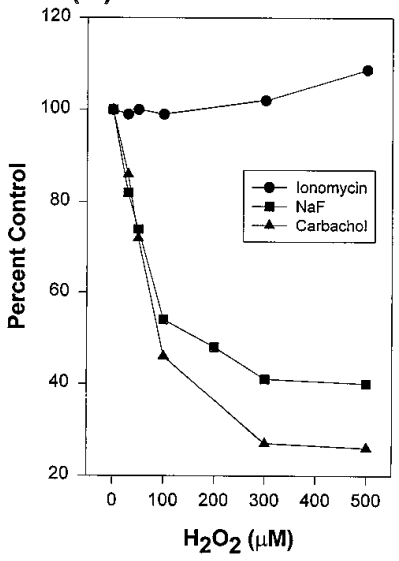

Figure 11. Inhibition by $\mathrm{H}_{2} \mathrm{O}_{2}$ of $\left[{ }^{3} \mathrm{H}\right]$ phosphoinositide hydrolysis. $\mathrm{SH}-$ SY5Y cells were prelabeled with $\left[{ }^{3} \mathrm{H}\right]$ inositol for $48 \mathrm{hr}$, resuspended in assay buffer, incubated for $10 \mathrm{~min}$ with the indicated concentration of $\mathrm{H}_{2} \mathrm{O}_{2}$ followed by the addition of $1 \mathrm{~mm}$ carbachol $(A), 20 \mathrm{~mm} \mathrm{NaF}$ (plus $\left.10 \mu \mathrm{M} \mathrm{AlCl}{ }_{3}\right)(B)$, or $50 \mu \mathrm{M}$ ionomycin $(C)$. After an additional incubation for $30 \mathrm{~min},\left[{ }^{3} \mathrm{H}\right]$ inositol monophosphate was measured as described in Materials and Methods. Values with each stimulant were corrected for basal $\left[{ }^{3} \mathrm{H}\right]$ inositol monophosphate production in each experiment, which are shown with squares. $D,\left[{ }^{3} \mathrm{H}\right]$ phosphoinositide hydrolysis was calculated as the percent of control values obtained from cells exposed to each stimulant in the absence of $\mathrm{H}_{2} \mathrm{O}_{2}$. Mean \pm SEM $(n=8-9)$. ${ }^{*} p<0.05$ compared with agonist stimulation in the absence of $\mathrm{H}_{2} \mathrm{O}_{2}$ (ANOVA with a post hoc Bonferroni test).

the inhibitory action of $\mathrm{H}_{2} \mathrm{O}_{2}$. Because phosphoinositide hydrolysis stimulated by direct activation of G-proteins was inhibited by $\mathrm{H}_{2} \mathrm{O}_{2}$, it is unlikely that there is selectivity for muscarinic responses in this modulatory effect, but responses to other receptors remain to be investigated.

Surprisingly, carbachol-stimulated $\mathrm{NF} \kappa \mathrm{B}$ was impervious to the inhibitory effect of low concentrations of $\mathrm{H}_{2} \mathrm{O}_{2}$ on phosphoinositide hydrolysis, which impaired the stimulation of AP-1. This suggested that different signaling pathways contributed to $\mathrm{NF} \kappa \mathrm{B}$ and AP-1 activation induced by carbachol, a proposal also supported by the 10 -fold difference in the carbachol $\mathrm{EC}_{50}$ for stimulation of $\mathrm{NF} \kappa \mathrm{B}(20 \mu \mathrm{M})$ and AP-1 $(2 \mu \mathrm{M})$. The mechanism of the resilience of carbachol-induced $\mathrm{NF} \kappa \mathrm{B}$ to $\mathrm{H}_{2} \mathrm{O}_{2}$ remains to be identified. However, the sensitivity of G-protein-activated phosphoinositide hydrolysis to inhibition by $\mathrm{H}_{2} \mathrm{O}_{2}$ may provide a clue to this problem. Because both the G-protein $\alpha$-subunits and the $\beta \gamma$-dimers constitute signaling elements, we speculate that bifur- cation of signaling at the level of the G-protein subunits may account for the differential responses of $\mathrm{NF} \kappa \mathrm{B}$ and $\mathrm{AP}-1$ to activation by carbachol and inhibition by $\mathrm{H}_{2} \mathrm{O}_{2}$. Thus, the subunit activating phosphoinositide hydrolysis that leads to AP-1 activation was susceptible to inhibition by $\mathrm{H}_{2} \mathrm{O}_{2}$, whereas the other signaling subunit leading to activation of $\mathrm{NF} \kappa \mathrm{B}$ remained unaffected except at the highest concentration of $\mathrm{H}_{2} \mathrm{O}_{2}$. Although the G-protein $\alpha$-subunit classically has been identified as the primary activator of phospholipase C, Clapham and colleagues (StehnoBittel et al., 1995) recently raised the intriguing possibility that the $\beta \gamma$-dimer fulfills this role. Thus, it remains to be determined which activated G-protein subunits are coupled to activation of $\mathrm{NF} \kappa \mathrm{B}$ and AP-1 after stimulation with carbachol and whether these are differentially susceptible to inhibition by oxidative stress.

The observations that carbachol caused a relatively prolonged activation of $\mathrm{NF} \kappa \mathrm{B}$ and AP-1 and that the effects of $\mathrm{H}_{2} \mathrm{O}_{2}$ persisted well beyond its lifetime demonstrate the prolonged signaling potential of these agents. Activation of $\mathrm{NF} \kappa \mathrm{B}$ is often a transient effect, but recent reports have identified conditions in which activation is more extended (for review, see Finco and Baldwin, 1995). Thompson et al. (1995) provided evidence that the release of $\mathrm{NF} \kappa \mathrm{B}$ from $\mathrm{I} \kappa \mathrm{B} \alpha$ mediates transient responses, whereas prolonged activation of $\mathrm{NF} \kappa \mathrm{B}$ is associated additionally with release from the inhibitory action of $\mathrm{I} \kappa \mathrm{B} \beta$. Similarly, stimulation of the levels of Fos-related antigens (e.g., Fra 1, Fra 2) has been associated with prolonged activation of AP-1 compared with more transient responses attributable to increased levels of c-Fos (Pennypacker et al., 1995; Hyman and Nestler, 1996). Regulation of the duration of activation of $\mathrm{NF} \kappa \mathrm{B}$ and $\mathrm{AP}-1$, and their eventual roles as mediators of apoptosis or cell survival, may depend on the selectivity of the inhibitory and constitutive proteins that are affected by stimulatory agents, an issue remaining to be addressed in identifying the responses to carbachol and to $\mathrm{H}_{2} \mathrm{O}_{2}$ in neuronal cells.

The inhibition by oxidative stress induced with $\mathrm{H}_{2} \mathrm{O}_{2}$ on cholinergic muscarinic receptor-stimulated signaling reported here is remarkably similar to impaired cholinergic responses observed in Alzheimer's disease brain in a number of studies. Notably, cholinergic agonist-induced phosphoinositide hydrolysis is severely impaired in Alzheimer's disease, and impaired G-protein function has been identified as a primary site causing this deficient phosphoinositide signaling (for review, see Jope, 1996). These impairments correspond remarkably closely to the $\mathrm{H}_{2} \mathrm{O}_{2}$-induced inhibition of cholinergic receptor- and G-protein-stimulated phosphoinositide hydrolysis in SH-SY5Y cells. Moreover, A $\beta$ peptides, which contribute to amyloid plaque formation in $\mathrm{Alz}$ heimer's disease, have been shown to induce neurotoxicity via oxidative stress mechanisms, including increasing the concentration of $\mathrm{H}_{2} \mathrm{O}_{2}$ (Behl et al., 1994; Hensley et al., 1994). Thus, impairments in signaling induced by $\mathrm{H}_{2} \mathrm{O}_{2}$ in SH-SY5Y cells may model some of the mechanisms contributing to neuronal dysfunction in Alzheimer's disease and other neurological disorders in which oxidative stress occurs.

\section{REFERENCES}

Abate C, Patel L, Rauscher FJ, Curran T (1990) Redox regulation of fos and jun DNA-binding activity in vitro. Science 249:1157-1161.

Behl C, Davis JB, Lesley R, Schubert D (1994) Hydrogen peroxide mediates amyloid $\beta$ protein toxicity. Cell 77:817-827.

Bradford MM (1976) A rapid and sensitive method for the quantitation of microgram quantities of protein utilizing the principle of protein dye binding. Anal Biochem 72:248-254. 
Coyle JT, Puttfarcken P (1993) Oxidative stress, glutamate, and neurodegenerative disorders. Science 262:689-695.

Finco TS, Baldwin AS (1995) Mechanistic aspects of NF- $\kappa$ B regulation: the emerging role of phosphorylation and proteolysis. Immunity 3:263-272.

Fisher SK (1995) Homologous and heterologous regulation of receptorstimulated phosphoinositide hydrolysis. Eur J Pharmacol 288:231-250.

Fisher SK, Domask LM, Roland RM (1989) Muscarinic receptor regulation of cytoplasmic $\mathrm{Ca}^{2+}$ concentrations in human SK-N-SH neuroblastoma cells: $\mathrm{Ca}^{2+}$ requirements for phospholipase $\mathrm{C}$ activation. Mol Pharmacol 35:195-204.

Friedlich AL, Butcher LL (1994) Involvement of free oxygen radicals in $\beta$-amyloidosis: an hypothesis. Neurobiol Aging 15:443-455.

Greenwood AF, Powers RE, Jope RS (1995) Phosphoinositide hydrolysis, $\mathrm{G} \alpha \mathrm{q}$, phospholipase $\mathrm{C}$, and protein kinase $\mathrm{C}$ in post mortem human brain: effects of post mortem interval, subject age, and Alzheimer's disease. Neuroscience 69:125-138.

Halliwell B (1992) Reactive oxygen species and the central nervous system. J Neurochem 59:1609-1623.

Hansen MB, Nielsen SE, Berg K (1989) Reexamination and further development of a precise and rapid dye method for measuring cell growth/cell kill. J Immunol Methods 119:203-210.

Hensley K, Carney JM, Mattson MP, Aksenova M, Harris M, Wu JF, Floyd R, Butterfield DA (1994) A model for $\beta$-amyloid aggregation and neurotoxicity based on free radical generation by the peptide: relevance to Alzheimer's disease. Proc Natl Acad Sci USA 91:3270-3274.

Hyman SE, Nestler EJ (1996) Initiation and adaptation: a paradigm for understanding psychotropic drug action. Am J Psychiatry 153:151-162.

Jope RS (1988) Modulation of phosphoinositide hydrolysis by $\mathrm{NaF}$ and aluminum in rat cortical slices. J Neurochem 51:1731-1736.

Jope RS (1996) Cholinergic muscarinic receptor signaling by the phosphoinositide signal transduction system in Alzheimer's disease. Alzheimer's Dis Rev 1:2-14.
Jope RS, Li X (1989) Inhibition of inositol phospholipid synthesis and norepinephrine-stimulated hydrolysis in rat brain slices by excitatory amino acids. Biochem Pharmacol 38:589-596.

Jope RS, Casebolt TL, Johnson GVW (1987) Modulation of carbacholstimulated inositol phospholipid hydrolysis in rat cerebral cortex. Neurochem Res 12:693-700.

Karin M, Smeal T (1992) Control of transcription factors by signal transduction pathways: the beginning of the end. Trends Biochem Sci $17: 418-422$.

Laemmli UK (1970) Cleavage of structural proteins during the assembly of the head of bacteriophage T4. Nature 227:680-685.

Pennypacker KR, Hong J-S, McMillian MK (1995) Implications of prolonged expression of Fos-related antigens. Trends Pharmacol Sci 16:317-321.

Shigenaga MK, Hagen TM, Ames BN (1994) Oxidative damage and mitochondrial decay in aging. Proc Natl Acad Sci USA 91:10771-10778.

Siebenlist U, Franzoso G, Brown K (1994) Structure, regulation and function of $\mathrm{NF}_{\kappa} \mathrm{B}$. Annu Rev Cell Biol 10:405-455.

Staal FJT, Roederer M, Herzenberg LA, Herzenberg LA (1990) Intracellular thiols regulate activation of nuclear factor $\kappa \mathrm{B}$ and transcription of human immunodeficiency virus. Proc Natl Acad Sci USA 87:9943-9947.

Stehno-Bittel L, Krapivinsky G, Krapivinsky L, Perez-Terzic C, Clapham DE (1995) The G-protein $\beta \gamma$ subunit transduces the muscarinic receptor signal for $\mathrm{Ca}^{2+}$ release in Xenopus oocytes. $\mathrm{J}$ Biol Chem 270:30068-30074.

Thompson JE, Phillips RJ, Erdjument-Bromage H, Tempst P, Ghosh S (1995) $\mathrm{I} \kappa \mathrm{B}-\beta$ regulates the persistent response in a biphasic activation of NF- $\kappa$ B. Cell 80:573-582.

Unlap T, Jope RS (1995) Diurnal variation in kainate-induced AP-1 activation in rat brain: influence of glucocorticoids. Mol Brain Res 28:193-200. 